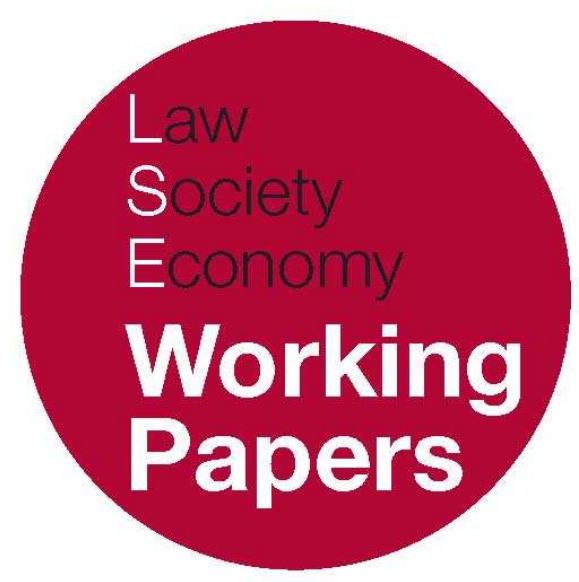

\title{
Should Agency Workers be Treated \\ Differently?
}

\author{
Ewan McGaughey \\ LSE Law, Society and Economy Working Papers 07/2010 \\ London School of Economics and Political Science \\ Law Department
}

This paper can be downloaded without charge from LSE Law, Society and Economy Working Papers at: www.lse.ac.uk/collections/law/wps/wps.htm and the Social Sciences Research Network electronic library at: http://ssrn.com/abstract=1610272.

(C) Ewan McGaughey. Users may download and/or print one copy to facilitate their private study or for non-commercial research. Users may not engage in further distribution of this material or use it for any profit-making activities or any other form of commercial gain. 


\title{
Should Agency Workers be Treated Differently?
}

\author{
Ewan McGaughey*
}

\begin{abstract}
The EU Temporary and Agency Work Directive created a right of equal treatment on working time and pay for agency workers compared to direct workers. This article asks, what justifications are there for any different treatment? Using job security rights as an example, this article explores the framework for regulation of employment agencies and the common law position of agency workers. It highlights, first, that profit-making agencies were frowned on historically by international law, and that principled regulation is required to prevent abuse. It shows, secondly, that the common law test of 'mutuality of obligation', that removes employment rights for agency workers, is legally and logically unsound. It then illustrates, third, that a recently developed test for implied contracts, which leads agency workers to have no employer at all, pays incomplete regard to the full authority on contractual and statutory construction. These loopholes are unfair and inefficient and amount to an unjustified subsidy for agency work. Simple recognition is needed that agency workers should not be treated differently, because work through an agency is work like any other.
\end{abstract}

\footnotetext{
* PhD candidate and graduate teaching assistant, Law Department, London School of Economics and Political Science, and part time tutor, King's College, London. For valuable discussions and comments, my deepest thanks go, in particular, to Hugh Collins, Paul Davies, Simon Deakin, Danny Fairfax, Toby Hall, Harry Jones, David Kershaw, Robert Knox, Domitille Lainey, Franck Lecomte, Peter Schüren, Edward Turner, Michael Watkins and an anonymous referee. And for the invaluable empirical side, my thanks also go to the hard working staff of the employment agencies that I have worked through and members of the staffing departments at various local authorities, particularly Greenwich London Borough Council, and the Employment Agency Standards Inspectorate.
} 


\section{INTRODUCTION}

After being dismissed from the Cowley Mini factory in February 2009, an agency worker of over two years, John Cunningham, told The Independent this: ${ }^{1}$

They've planned this for months and we've only just been told - one hour's notice. We've been given a week's pay for an enforced week off, which I suppose is a week's notice. I don't know what's going to happen to me and my family. It's very scary.

There have, since early 2009, been many reasons to be optimistic about the improvement of agency workers' positions in the United Kingdom. Due to more high profile press coverage and recent legislative reform, agency workers like John are gradually becoming less invisible. In 2005 the Labour Force Survey reported there were fewer than 260,000 . Now the number is generally acknowledged to be over $1,300,000 .^{2}$

Yet it is clear that most agency workers are being treated differently under the Employment Rights Act 1996. ${ }^{3}$ This gives rights to 'employees'. 'Employee' has a common law meaning, so the self-employed do not benefit from minimum, mandatory rights. ${ }^{4}$ Take the example of job security. After one month employees have the right to one week's notice before dismissal. After one year employees have a right to be dismissed fairly. After two years employees have the right to two weeks' notice and redundancy pay. 5 The notice period (always substitutable with a payment reflecting wages, in lieu of notice) and the right to redundancy increase according to the number of years in employment. ${ }^{6} \mathrm{Had}$ he been a Mini employee,

1 A. Jones, 'Fury as 850 Mini Workers Given Hour's Notice' (16 February 2009) The Independent; T. Macalister and H. Pidd, 'Uproar in Cowley as BMW Confirms 850 Job Cuts at Mini Factory' (16 February 2009) The Guardian; Editor, 'Job Cuts at Mini Spark Angry Rows' (16 February 2009) BBC News online; in September 2009 BMW's press officer told reporters that temporary workers were being rehired, see J. Reed and R. Milne, 'BMW Refuels Mini Adventure with Two New Models for Oxford Plant' (3 September 2009) Financial Times.

2 See the Office for National Statistics, Labour Force Survey: Quarterly Supplement (April 2005) 20; Department for Business Enterprise and Regulatory Reform, Implementation of the Agency Workers Directive: A Consultation Paper (May 2009) 4.

${ }^{3}$ Employment Rights Act 1996 (hereafter 'ERA 1996').

${ }^{4}$ Examples include the right to a written statement of one's contract (s 1), to request flexible working time (s $80 \mathrm{~F}$ ), to have time off to raise children (Part VIII), to state compensation for lost earnings when an employer enters an insolvency procedure (s 182), to information and consultation about business changes and redundancies (ICER 2004 r 20), or to not be dismissed for union involvement (TULRCA 1992, s 152).

${ }^{5}$ ERA 1996, n 3 above, ss 86(1)(a), 94, 135. Unfair dismissal functions less as an assurance that dismissals will be objectively 'fair', but that an employer should not dismiss if it is so unreasonable that 'no reasonable employer would have dismissed,' British Leyland UK Ltd v Swift [1981] IRLR 91. Also, if a disciplinary procedure is not followed, but the same result would have been reached if it had, the dismissal is unaffected, Polkey v AE Dayton Services Ltd [1988] ICR 142.

${ }^{6}$ An employee aged between 22 and 40 receives one week's pay for each year she has worked. This is reduced to half a week's pay for the time worked before her $21^{\text {st }}$ birthday, and increased to one and a half week's pay for years worked past her 41st birthday (ERA 1996, n 3 above, s 162). 
John would have had two weeks' notice before dismissal and received a redundancy payment. Furthermore, because over 100 people were being dismissed, he would have received 90 days warning and consultation. ${ }^{7}$ But John was not considered an employee. He was an agency worker. He was by-him-selfemployed.

The implementation of the EU Temporary and Agency Work Directive (2008/104/EC, the 'Directive') is the occasion for reform. The Directive enforces transnational minimum standards on agency work for the first time. Many UK agency workers are treated as employees, with employee rights. ${ }^{8}$ But many are not, and all live in legal limbo. ${ }^{9}$ This article draws on the example of job security rights to argue no justification exists for any differential treatment. The first part examines the emerging regulatory framework of agency work. The second part analyses the common law definition of 'employee' and demonstrates why the current component of 'mutuality of obligation' is defective, circular and unprincipled. The third part focuses on the 'employer', and shows that recent decisions have overlooked an important range of authority on implied terms and contracts. The article rests on the presumption that different treatment of agency workers requires positive justification, but suggests that such justifications for different treatment are absent. Given the present economic instability and potential for persistent long-term unemployment, it is more important than ever that clear rules exist to promote fairness and productive efficiency.

\section{EQUALITY AND EFFICIENCY: THE DIRECTIVE AND REGULATION}

\section{NEW DIRECTIONS?}

The new Directive adds a tenth category of protected status to workplace equality policy..$^{10}$ Originally intended to accompany directives on fixed-term and part-time work, ${ }^{11}$ it is classic anti-discrimination legislation. It creates the right to equal treatment in 'basic working and employment conditions'. This means the pay

\footnotetext{
7 TULRCA 1992, n 4 above, ss 188-189.

8 See, eg, McMeechan v Secretary of State for Employment [1997] ICR 549, Manpower UK Ltd v Vjestica (Unreported, 18.10.2005) UKEAT/0397/05/DM.

${ }^{9}$ See Montgomery v Johnson Underwood Ltd [2001] EWCA Civ 318 at [42]; [2001] IRLR 269, 275.

10 The number ten comes from the current array of statutes and statutory instruments. The ten are (1) agency work, (2) part time work, (3) fixed term employment, (4) union membership, (5) gender, (6) race, (7) disability, (8) age, (9) sexual orientation, and (10) belief. The latter six were codified in the Equality Act 2010, which explicitly protects marital status and gender reassignment as separate statuses (ss 5-12).

11 See EU Temporary and Agency Work Directive (2008/104/EC), Preamble (2) and (4) and the Fixed Term Employees (Prevention of Less Favourable Treatment) Regulations 2002, and Part-time Workers (Prevention of Less Favourable Treatment) Regulations 2000; note the recent exemption under FTER 2002 r 19(1).
} 
workers receive and their working time.12 Equality in benefits for women caring for children and anti-discrimination provisions are added. ${ }^{13}$ Agency workers will have a pay and working time claim compared to the hypothetical conditions 'that would apply if they had been recruited directly by that undertaking to occupy the same job'.14 It therefore appears direct staff cannot benefit from the Directive, though most evidence suggests that UK agency workers are chiefly paid less than direct staff for the same jobs. ${ }^{15}$ When calculating working time or pay it may be that a court would accept evidence of 'compensating advantages', ${ }^{16}$ for instance where an agency worker forgoes membership of a company superannuation plan for extra pay per hour. All such benefits could be measured in money. Further rights for agency workers that the Directive explicitly enforces deal with workplace participation. Article 6 says agency workers are entitled to the same access to employment and vocational training facilities. An example could be that an agency worker in a government department should be able to access the civil service's internal job advertisement network. This provision reinforces the idea of temporary work as a stepping-stone to a secure job, rather than an end in itself. ${ }^{17}$ Article 7 requires that agency workers are counted for the purpose of union recognition and article 8 requires that agency workers are informed and consulted like any other worker. The Directive sets down minimum transnational standards, but does not prevent individual countries providing greater protection. ${ }^{18}$

The equal treatment principle has a number of exceptions. Article 5(2) allows member states to set conditions for differential pay, after consulting social partners, if the worker is the agency's permanent employee and is paid between assignments. Article 5(3) allows derogations if made through industry level collective agreement. Both pay between assignments and industry level collective agreement have stronger traditions in continental Europe and currently matter little to the UK context. But both of these provisions show that derogations are being allowed where sufficient safeguards exist. As exceptions, European Courts would construe them restrictively. ${ }^{19}$ The safeguards are slim, however, in the article 5(4) exception, which allows member states to have a qualifying period for equal conditions where social partners have agreed it. ${ }^{20}$ In the UK, the Trades

\footnotetext{
${ }^{12}$ EU Temporary and Agency Work Directive, ibid, Art 3(1)(f); working time means 'duration of working time, overtime, breaks, rest periods, night work, holidays and public holidays'.

13 ibid, Art 5(1); it is unclear whether discrimination protection was a necessary change for the UK. See Part 4 A below.

14 ibid, Art 5(1) 'for the duration of their assignment at a user undertaking, at least those that would apply if they had been recruited directly by that undertaking to occupy the same job.'

${ }^{15}$ eg TUC, Agency Workers: Counting the cost of flexibility (2007) 7.

16 cf Power v Regent Security Services Ltd [2007] EWCA Civ 1188; [2008] ICR 442 and GMB v Allen [2008] EWCA Civ 810; [2008] ICR 1407.

17 In 1976, the forerunner of the Recruitment and Employment Confederation supported this view. See, The Federation of Personnel Services of Great Britain Ltd, The Private Employment Agencies: A Survey of Services to Permanent and Temporary Office Workers (LSE library reference, Folio FHDS/F92) 2.

${ }^{18}$ EU Temporary and Agency Work Directive, n 11 above, Art 9(1).

${ }^{19}$ See, eg, T-14/98 Hautala v Council [1999] ECR II-2489, para 84.

${ }^{20}$ The previous draft, COM (2002) 149 final, mandated a six week qualifying period.
} 
Union Congress negotiated twelve weeks with the Confederation of British Industry. ${ }^{21}$ This could change. Member states must ensure 'an adequate level of protection is provided', a stipulation probably best met if no qualifying period existed. It is not entirely clear what principle (other than 'compromise') can justify any qualifying period, just as one would not wish to have a qualifying period for equal treatment of part-time workers, or the elderly.

Viewed from the perspective of equal treatment, the Directive is welcome. ${ }^{22}$ The common law has no generally articulated principle of equal pay for work of equal value, ${ }^{23}$ even though it is axiomatic that like cases should be treated alike. ${ }^{24}$ But does the Directive solve a key problem facing UK agency workers, that they can be fired at will and have no rights because the common law has not treated them as 'employees'? In article 2 the Directive states its aim to 'ensure the protection of temporary agency workers and to improve the quality of temporary agency work $[\ldots]$ by recognising temporary-work agencies as employers $[\ldots]^{25}$ Does 'recognising temporary-work agencies as employers' mean that an agency worker must be regarded as an employee of, at least, the agency? Article 3(2) states the Directive is without prejudice to the member state's definition of 'contract of employment'. Yet it is a slight semantic tightrope to say that if A is the 'employer' of $\mathrm{B}$, then $\mathrm{B}$ is not 'employee' of $\mathrm{A} .{ }^{26}$ 'This is an anti-discrimination Directive and it is within the competence of the EU to combat social exclusion of agency workers. ${ }^{27}$ The EU need not be taken to have said that member states must enforce job security or other employment rights. But if member states do have such rights, then arguably a class of workers cannot be left out merely because they work through an agency. It could mean that the common law should be developed consistently with EU principles. This accords with understandings of legislators in the European Parliament. ${ }^{28}$ But if it is true, why was the Directive not clearer?

\footnotetext{
21 Agency Workers: Joint Declaration by the Government, the CBI and the TUC (20 May 2008).

${ }^{22}$ For more detailed treatment, written with reference to the Government's first consultation, see N. Countouris and R. Horton, 'The Temporary Agency Work Directive: Another Broken Promise?' (2009) 38(3) ILJ 329.

23 cf Transco plc v O'Brien [2002] EWCA Civ 379; [2002] ICR 721, Pill LJ held it broke mutual trust and confidence to not improve with permanent staff the redundancy package of a man who had just moved from an agency to direct employment.

${ }^{24}$ For (qualified) judicial support of the principle, see Carson v United Kingdom (2009) 48 EHRR 41, 77; Matadeen v Pointu and Minister of Education and Science [1999] 1 AC 98, 109.

${ }^{25}$ EU Temporary and Agency Work Directive, n 11 above.

${ }^{26}$ See also, ibid, Art 3(1)(c): “"temporary agency worker" means a worker with a contract of employment or an employment relationship with a temporary-work agency with a view to being assigned to a user undertaking to work temporarily under its supervision and direction.'

27 Treaty on the Functioning of the European Union, Art 153(j).

28 eg C. Moraes MEP, 'Letter: EU Directive Too Late for Cowley Workers' (19 February 2009) The Guardian.
} 


\section{THE DiRECTIVE's BACKGROUND}

Part of the answer may be found in Germany, where recent legal reforms sound a striking chime with the new Directive's scheme. ${ }^{29}$ In 2004, Gerhard Schröder's Social Democrat government changed its Arbeitnehmerüberlassungsgesetz. (Employee Leasing Act) based on the 2002 Hartz I report. ${ }^{30}$ They abandoned a two year limit on duration of agency work contracts and in return mandated equal treatment on pay, working time, parental and anti-discrimination rights. ${ }^{31}$ The Hartz report came at the same time as a previous Draft Agency Worker Directive (COD 2002/0149) was produced. ${ }^{32}$ In the 2002 Draft and the new Directive alike, the muted position on employee status and further rights mirrored the concerns in Germany. Regardless of whether one works through an agency, all German workers are already entitled to at least two weeks' notice. ${ }^{33}$ The right to fair dismissal arises after six months in all German workplaces with over ten employees. ${ }^{34}$ German Works Councils enforce redundancy payments, customarily valued at half a month's pay per year of employment. ${ }^{35}$

Even though the 2002 Draft never addressed all the problems of agency workers, the TUC pushed for its implementation. Progress was slow. In James v Greenwich LBC Mummery LJ remarked of a 2007 Private Member's Bill, that it was 'doomed to failure for lack of support from the Government'. ${ }^{36}$ But that Bill was renamed and reintroduced in early $2008 .{ }^{37} \mathrm{~A}$ well organised publicity campaign brought the 2008 Bill to pass a second reading. The government resolved to act,

\footnotetext{
${ }^{29}$ See A. Freckmann, 'Temporary Employment Business in Germany' (2004) 15(1) International Company and Commercial Law Review 7.

30 See P. Hartz, 'Moderne Dienstleistungen am Arbeitsmarkt: Vorschläge der Kommission zum Abbau der Arbeitslosigkeit und zur Umstrukturierung der Bundesanstalt für Arbeit' (Berlin 2002) Bericht der Kommission, Norbert Bensel et al (43 (2537)); Die Hartz-Reform: Neue Dynamik für den Arbeitsmarkt? (Bonn: 2002). Peter Hartz was the former Volkswagen AG labour executive, a member of a German public company's management board devoted specially to staff issues under the Mitbestimmungsgesetz (Codetermination Act 1976), s 33.

31 B. Waas, 'Temporary Agency Work in Germany: Reflections on Recent Developments' (2003) 19(3) International Journal of Comparative Labour Law and Industrial Relations 387; B. Keller, 'The Hartz Commission Recommendations and Beyond: An Intermediate Assessment' (2003) 19(3) International Journal of Comparative Labour Law and Industrial Relations 363.

32 See C. Mortished, 'UK Turns Against EU Merger Law in Deal with Germany' (19 May 2003) The Times, which suggests that German traded delay of the Agency Worker Directive for Britain's agreement to delay the Takeover Directive. The latter was in fact introduced before long: see EU Directive 2004/25/EC.

33 Bürgerliches Gesetzbuch, s 622(3). After six months, the minimum period is 4 weeks, and the period rises up to a seven-year minimum for twenty years of work. See generally, A. Freckmann, 'Termination of Employment Relationships in Germany - Still a Problem' (2005) 16(1) International Company and Commercial Law Review 38.

${ }^{34}$ Kündigungsschutzgeset\%, s 1(1).

35 See S. Konnert, 'Unfair Dismissal by Reason of Redundancy in Germany' (2005) 16(11) International Company and Commercial Law Review 431, 440.

36 [2008] EWCA Civ 35 [57], commenting on the Temporary and Agency Workers (Prevention of Less Favourable Treatment) Bill.

37 Temporary and Agency Workers (Equal Treatment) Bill.
} 
though through Europe instead. It was agreed that passage in Parliament would stop.

Now that agency standards are being Europeanised, is it enough to enforce equal pay and hours? The rationale for all European legislation is that it achieves aims which cannot be achieved through national government. Harmonising employment rights means individual countries are not forced to undercut one another in a regulatory race to the bottom, under temptation to attract investment. ${ }^{38}$ Similarly, responsible employers who wish to treat staff as members, not resources, are not undercut by the unscrupulous leading the competition. When liberalisation of national laws leads to a globalising economy, law itself needs to globalise to support the broadened market. But if this logic is correct, then a simple implementation of the Directive will not end the race to the bottom in Europe. Without job security rights, British workers can still be seen as 'low cost', and before long, other countries will cut their standards to compete with us, prompting us to become lower cost once more. It might be argued that protectionist EU policy will not stop capital flows to developing countries and a race to the bottom globally. Yet a plain counter-argument is that European legislation will slow that downward spiral, and in the meantime work can be done to enforce or raise standards internationally. One cannot begin nowhere. In this respect, the International Labour Organisation plays a vital coordinating role. And historically it would have had a radical answer to the UK's problems. It would have abolished employment agencies. If employment agencies do not exist, there can be no agency workers to treat differently.

\section{WHY NOT ABOLISH AGENCIES?}

Though it may seem a far fetched idea to contemporary eyes, abolishing agencies was a policy with a long international pedigree. ${ }^{39}$ An important starting point is 1912, when the United States Labor Department submitted to Congress documentation of abuses by agencies. Across many states new regulations were introduced in response. Before long the regulations were challenged under the US constitution. ${ }^{40}$ In Adams v Tanner, an employment agent was prosecuted for charging fees to workers after the state of Washington had, following a referendum envisaging full abolition, prohibited fees. The US Supreme Court held, five to four, that the law was contrary to the Fourteenth Amendment's due process clause. Reading for the majority (White CJ, Day, Van Devanter and Pitney

\footnotetext{
${ }^{38}$ In a company law context, see Brandeis J, Liggett Co v Lee, 288 US 517, 559 (1933), drawing inspiration from A. A. Berle and G. C. Means, The Modern Corporation and Private Property (1932) 206, fn 18.

${ }^{39}$ See generally, T. Martinez, The Human Marketplace: An Examination of Private Employment Agencies (New Brunswick: Transaction, 1976); HL Deb vol 343 col 342-346 (Earl of Gowrie); Employment Services Agency, Temporary Workers. A Report of an Inquiry for the Employment Services Agency, Social Survey Division, Office of Population, Census and Surveys, s 1059 (London: September 1976); and during the short-lived Second Republic in France, Décret 8 Mars 1848.

${ }^{40}$ See also, Brazee v Michigan 241 US 340 (1916), where mandatory licensing was held to be compliant with the fourteenth amendment, but McReynolds J said obiter dicta that regulation of fees would not be; Ribnik. v McBride 277 US 350 (1928).
} 
JJ) McReynold J argued, 'there is nothing inherently immoral or dangerous to public welfare in acting as paid representative of another to find a position in which he can earn an honest living. On the contrary, such service is useful, commendable, and in great demand. ${ }^{41}$

He found support for the argument that private employment agencies were useful in the fact that many states were establishing free public employment agencies. But Brandeis J (with whom Holmes, Clarke and McKenna JJ dissented) highlighted the US Labor Department's accounts of abuse, attempts in over thirty states to regulate and have free public agencies compete. He emphasised the legitimacy of the view that all methods short of abolition had ultimately failed. ${ }^{42}$ Some of the most serious mischief was agencies charging destitute jobseekers upfront fees and making no effort to place the worker. Work could last a few days, and the agent would split the next fee with the employer and bring in fresh replacements. But Brandeis $\mathrm{J}$ also emphasised the wider economic effects of agencies, quoting from the 1912 US Labor Department report:

They also fail to meet the problem [of unemployment] because they are so numerous and are necessarily competitive. With few exceptions, there is no cooperation among them. This difficulty is further emphasized by the necessity of paying the registration fees required by many agencies; obviously the laborer cannot apply to very many if he has to pay a dollar at each one. ${ }^{43}$

The views in this dissent were shared internationally. After the First World War the International Labour Organisation was established through the Treaty of Versailles, which proclaimed that since 'peace can be established only if it is based on social justice', 'labour should not be regarded merely as a commodity or an article of commerce'. ${ }^{44}$ Private employment agencies were seen to be dealing solely in the extraction of a worker's surplus value. So the ILO's first ever Recommendation urged member states,

to prohibit the establishment of employment agencies which charge fees or which carry on their business for profit. Where such agencies already exist, it is further recommended that they be permitted to operate only under government licenses, and that all practicable measures be taken to abolish such agencies as soon as possible. ${ }^{45}$

\footnotetext{
41244 US 590 (1917).

42244 US 601-9 (1917).

43244 US 604 (1917).

44 Part XIII and Art 427; See also, P O'Higgins, 'Labour Is Not a Commodity - An Irish Contribution to International Labour Law' (1977) 26(3) Industrial Law Journal 225.

45 ILO Unemployment Recommendation 1919 (No 1), Art 1.
} 
The ILO's Convention No 2 gave the alternative. ${ }^{46}$ Member states were to establish public employment agencies. ${ }^{47}$ In 1933, Convention No 34 formally called for abolition of fee charging agencies. Many continental European countries adopted these laws. The United Kingdom never did, and state governments in America were bound by the US Supreme Court to reject them, until Franklin Roosevelt's presidency. 48

By 1949 the ILO had changed. Convention No 96 allowed an opt-out, so private agencies could exist if monitored through licenses and if fees were prohibited. ${ }^{49}$ But many European countries maintained strict controls on, or prohibition of, private agencies till the 1990s. Then the European Court of Justice signalled a more active approach to market liberalisation through competition law. The leading case, Höfner and Elser v Macrotron GmbH, ${ }^{50}$ concerned the free public employment agency, the German Bundesanstalt für Arbeit (Federal Employment Office). Its monopoly on work placement services and a corresponding provision, that contracts in breach of the exclusive rights were void, were challenged. Many normal agencies simply acquired licenses, but the Bundesanstalt had taken a different approach to private executive headhunting agencies like Herr Höfner and Elser's. A 'blind eye' was turned for the purposes of oversight, but these executive agencies still risked that their contracts were unenforceable. The ECJ held that the maintenance of exclusive rights could amount to an abuse of a dominant position where, as here, a public service was not fully meeting demand..$^{51}$ The ECJ held that competition law could apply to public bodies, as well as private ones, since any organisation engaged in 'economic activity' would be an 'undertaking' subject to monopolies regulation. ${ }^{52}$ Italy was made to abandon a prohibition on private agencies in $1997.5^{53}$ The same year the ILO passed Convention No 181. This endorses profit making employment agencies, while recommending licenses, no upfront fees and the enforcement of employment rights. 54

It is apparent that under both EU law and US law private agencies could be abolished. The Höfner requirement is simply that a public service factually satisfies work placement demand. The US Supreme Court renounced Adams in the 1940s. Nevertheless, good arguments against abolishing private employment agencies exist. Firstly, whether public or private, employment agencies,

\footnotetext{
46 See also, M. Freedland, P. Craig, C. Jacqueson, and N. Countouris, Public Employment Services and European Law (Oxford: OUP, 2007); for the position in the United States, see D.E. Balducchi, R.W. Eberts, and C. J. O'Leary, Labor Exchange Policy in the United States (Kalamazoo: WE Upjohn Institute for Employment Research, 2004).

47 ILO Unemployment Convention 1919 (No 2), Art 2.

48 Lincoln Union v Northwestern Co 335 US 535 (1949). See also Olsen v State of Nebraska 313 US 236 (1941).

${ }^{49}$ ILO Convention 1949 (No 96); many US states still allow fees, eg New York's Employment Agency Law Art 11; for a useful contemporary overview of the EU member states' situations, see Opinion of the Advocate General in Case 35/70 Manpower SÀRL v Caisse Primaire d'Assurance Maladie de Strasbourg [1971] CMLR 222.

${ }^{50}$ Case 41/90 [1991] ECR I-1979.

51 ibid at [31], now under Treaty on the Functioning of the European Union, Art 102.

52 See now, Treaty on the Functioning of the European Union, ibid.

53 See Case 55/96 Job Centre Coop arl [1997] ECR I-7119.

${ }^{54}$ ILO Private Employment Agencies Convention 1997 (No 181), Arts 3(2), 7(1), 11, and 12.
} 
- promote specialisation and expertise in hiring staff. Arguably jobs can be more quickly done when the functions of labour are freely divisible to suit business' needs.

- channel workers to work. They may have a superior network effect to alternatives like newspaper advertising. If a worker knows that an agency specialises in jobs of a particular field, she may approach the single agency rather than writing many applications to many employers. Likewise, employers will learn to choose agencies with a reputation for getting staff of particular qualifications.

It can always be argued that since a public service can do all these things, and since a public employment agency would not keep a worker attached to its payroll once work is found, private agencies should still be abolished and problems regarding equality and employment rights need not exist. But it would also appear that in this particular industry,

- the existence of a private market does not sap significant expertise from the public service. Staff recruitment is not a job over which a small group of people may exercise a natural monopoly ${ }^{55}$ or where high barriers to entering the market exist.

- the market for jobs is dynamic and changing. Arguably agencies motivated by profit will actively seize upon new demands for services quicker than an expert civil servant, who may be more suited to industries where people's basic needs change less. In this way a private market can perform innovative functions better. Where it cannot, it will lose the competition to a public service.

Today no prohibitions exist in economically developed countries, because properly regulated private employment agencies are seen as valuable players in matching workers to work. The quicker people find jobs, the less short-term unemployment. To make it work, however, proper regulation appears to be key. So what regulation exists today?

\section{REGULATION TODAY}

In the UK, as in France and Germany, the present regulatory framework evolved in the 1970s.56 All three countries introduced laws requiring employment agencies

55 A term used in economics, first by J.S. Mill, Principles of Political Economy (1848) Book II, ch XIV, para $13-4$.

56 See C. Vigneau, 'Temporary Agency Work in France' (2001-2) 23 Comparative Labour Law \& Policy Journal 45; P. Schüren, 'Employee Leasing in Germany: The Hiring Out of an Employee as a Temporary 
to obtain licences and prohibit upfront fees to workers. ${ }^{57}$ But a highly significant difference was that France and Germany specified that an employment agency would have the responsibility to the worker for the purpose of employment rights. In the UK it appears to have been presumed in the courts, but not codified in the Employment Agencies Act 1973.58 In 1994, licensing was scrapped from the UK scheme.59 The Secretary of State gained discretion to make prohibition orders against agencies (confusingly called 'employment businesses' under the Act) ${ }^{60}$ if regulation breaches are disclosed in court cases. ${ }^{61}$

The relevant regulations are the Conduct of Employment Agencies and Businesses Regulations 2003.62 These restrict agencies for example, selling other services, strike breaking, sharing personal details and advertising jobs that do not exist. ${ }^{63}$ The 1973 Act itself prohibits upfront fees, unless one is an actor, model (including for clothing, hair and makeup), musician or sportsperson. ${ }^{64}$ Fees can also be charged by an agency to a client who offers a temporary worker a permanent contract. ${ }^{5}$ Breaching a regulation can mean a maximum penalty of $f^{5}, 000$, plus any civil damages. ${ }^{66}$ The task of enforcement of the regulations falls to the Employment Agency Standards Inspectorate (EASI). In 2004 EASI had 12 inspectors and 4 call centre staff. To illustrate the problem in this $f_{27}$ billion industry, ${ }^{67}$ in 2004 EASI investigated 1,057 complaints and procured 8 convictions. ${ }^{68}$ Workers received a total of $£, 5,735$ in compensation. ${ }^{69}$ That same year twenty-three cockle pickers, recruited by a clandestine employment agent, drowned in Morecambe Bay. ${ }^{70}$ The Gangmasters Licensing Authority was

Worker' (2001-2002) 23 Comparative Labour Law \& Policy Journal 67; B.A. Hepple and B.W. Napier, 'Temporary Workers and the Law' (1978) 7 Industrial Law Journal 84, 98.

57 In the UK, see Employment Agencies Act 1973, ss 1 and 6 (hereinafter 'EEA'), but note CEABR 2003, r 26 and Sched 3; it appears that it had been an unfulfilled promise of the Atlee government in 1951 to implement ILO Convention No 96, Hansard HL vol 343 col 330 ff 8 June 1973, though in fact the Bill was introduced by Conservative backbencher Kenneth Lewis MP.

58 eg Processed Vegetable Growers Association Limited v The Commissioners of Customs and Excise [1974] 1 CMLR 113 at [27], per Kenneth Suenson-Taylor QC, 'an employment agency [...] with a view to gain, provides the services of its employees for a consideration.'

${ }^{59}$ Deregulation and Contracting Out Act 1994, s 35 and Sched 17.

${ }^{60}$ Confusingly, EAA 1973, s 13 defines what is commonly called an agency as an 'employment business', while an 'employment agency' is defined as merely a one off matching service, that maintains no further relation with the placed person. 'Businesses' are regulated more, and are the focus of this article. However, the UK statutory terminology is avoided because it is out of sync with common usage, the Directive and the ILO Conventions.

${ }^{61}$ EAA 1973, s 3A.

62 SI $2003 / 3319$.

${ }^{63}$ CEABR 2003, n 57 above, rr 5, 7, 27, 28.

${ }^{64}$ EAA 1973, n 57 above, s 6 and CEABR 2003, n 57 above, r 26 and Sched 3, as expanded by SI $2007 / 3757$, r 10.

${ }^{65}$ CEABR 2003, n 57 above, $r 10$

${ }^{66}$ EAA 1973, n 57 above, s 5(2), Criminal Justice Act 1982, s 37 and CEABR 2003, n 57 above, r 30.

${ }^{67}$ The $f_{2} 27 \mathrm{~b}$ figure is quoted on http://www.rec.uk.com/aboutrec (last visited 4 Oct 2009).

${ }^{68}$ HC Hansard col 284W 5 July 2005.

${ }^{69} \mathrm{HC}$ Hansard col 1455W 23 June 2004.

70 'Five Charged over Morecambe Bay Disaster' (22 December 2004) The Guardian; See also, with somewhat inventive solutions, R. Wellings and J. Blundell, 'The Morecambe Bay Cockle Pickers: Market Failure or Government Disaster?' (2004) 24(3) Economic Affairs 69, 71: 'these migrant workers came to the UK to escape the poverty created by socialism in China and were working under a regime of state- 
established under the Gangmasters (Licensing) Act 2004. Licensing was reintroduced for agencies in agricultural, shellfish and packing industries. ${ }^{71}$ Then the Employment Act 2008 doubled the number of inspectors, and productivity at EASI has risen dramatically. Since individual claims concerning regulatory breaches are absent from the case reports, administrative enforcement seems important.

Yet the overall regulatory picture appears haphazard. Firstly, it is unclear why two bodies, EASI and GLA, are needed for essentially the same employment agency industry. Given the agency industry turns over $f_{2} 27$ billion and there are around 1.3 million agency workers, a combination of such government bodies and their expert staff doing similar work may be desirable from an efficiency standpoint. Secondly, it is unclear why licensing is not mandatory across the board. When licensing was abolished in 1994 the point does not appear to have been debated in Parliament. As a practical example, an agency that could provide food packing and food transporting services is incentivised to drop packing in order to avoid the 2004 Act's licensing requirement. Potential synergies are lost. The threat of license revocation would make the regulations real. Inconsistent enforcement is unfair on law abiding agencies. Indeed, the new Directive presupposes that licensing is necessary for a properly functioning labour market. ${ }^{72}$

Thirdly, there seems to be no real justification for exceptions in arts and sports to the prohibition on fees. Upfront fees are a barrier to jobs, can reach high levels without any promise of work and have attracted considerable criticism. ${ }^{73}$ Similarly, 'temp-to-perm' fees between agencies and the end-user clients have a frustrating effect on direct employment. Agencies want such fees to boost income. But the corresponding cost may be prolonged over-management of workers.

Fourthly, it would be desirable that fees that are charged by agencies to clients are disclosed to the parties involved. The Equality Act 2010 prohibits confidentiality, or 'gagging clauses' to increase the efficacy of equal pay rules..$^{74}$ This is a good model. Without transparency, it is difficult for workers to know that they are being unequally paid. Another aspect is that neither the client nor worker may realise that the agency takes home more than the worker herself. Many clients will want to know how much of their money is going to the worker, so the worker does not feel like an undervalued and demotivated 'temp'. So it would be desirable that the contracts between each of the three parties disclose who gets what. This would make the Directive's principle of equal pay function 'on the ground'.

regulated access to the cockle beds. An alternative market-orientated regime of private property rights in the cockle beds might have prevented the tragedy.'

71 GLA 2004, s 7.

72 EU Temporary and Agency Work Directive, n 11 above, Art 4(1), (4) and Preamble, recital 18.

73 See Department for Business, Enterprise and Regulatory Reform v Adam [2008] EWHC (Admin) 772; Inside Out, 'Model Agency' BBC South West (1 Oct 2007): 'I think it's outrageous,' said Jean Rogers, an expert on modelling. 'No reputable agency ever charges an up front fee of any description.'

${ }^{74}$ See Equality Act 2010, s 77. 
The justifications put forward here for the Directive and better regulation have so far been economic ones, which work in everybody's interest by ensuring a more stable, efficient and productive labour market. But if agency workers can still be treated differently because of their employee status, then international regulatory competition problems persist. On a national level, a further problem is that agencies may be used, not because they are more efficient overall at matching work to workers, but merely because they facilitate a transfer of wealth from the worker to the employer. If an employer (rationally or not) thinks it will save money by recruiting a 'temp' from an agency and does so because 'employee' rights (which it perceives to be costly, rationally or not) do not exist, then the agency is not being used because it does good work. It is merely a mechanism to flout rights and produces an unjustified subsidy to the agency industry. This would result in social waste because workers are being over-managed and private industry is becoming over-bureaucratised. This situation cannot be reasonably condoned. So why is it uncertain whether agency workers are 'employees'?

\section{THE IMPORTANCE OF HAVING PURPOSE: THE 'EMPLOYEE' ISSUE}

\section{THE THIRD WAY}

A defining moment in the agency worker story took place when a young $\mathrm{Mr}$ Anthony Blair arrived at the Employment Appeal Tribunal in Nethermere (St Neots) $L t d \mathrm{v}$ Gardiner. ${ }^{75}$ Blair was defending the employer against the claims of two ladies for unfair dismissal, after a dispute over holiday pay. Paid by the piece, Mrs Taverna sewed pockets onto trousers for five to seven hours a day, and had twelve and nine week breaks in the previous two years. Mrs Gardiner worked five hours a day and had four and one week gaps in work. Blair's central submission was that no 'mutuality of obligation' existed, without which he asserted there could be no employment contract. The meaning he sought to advance was that 'mutuality' meant a 'continuing relationship', or a continuing duty to offer and accept work. Tudor Evans J rejected this argument, and particularly the spin that Blair had put on the test. ${ }^{76}$ Upholding the decision in the Court of Appeal, Stephenson LJ emphasised that the 'mutuality' in an employment relation is that the employer gives a wage and the employee provides her work and skill. This was, he said, the

\footnotetext{
75 [1983] ICR 319, decided on 12 November 1982.

76 The original idea for 'mutuality of obligation' appeared with very different intentions in M. Freedland, The Contract of Employment (Oxford: Clarendon, 1976) 21-22, and was deployed (unsuccessfully) with its current meaning for the first time by counsel for the employer, Mr R. J. Walker, in Airfix Footwear Ltd v Cope [1978] ICR 1210, 1213.
} 
'irreducible minimum of obligation on each side to create a contract of service. ${ }^{77}$ It was the same as 'consideration'.

However between Blair's Employment Appeal Tribunal submissions and Stephenson LJ's affirmation that they were misplaced were two critical cases. The first case was Wickens v Champion Employment. ${ }^{78}$ Miss Wickens claimed she was dismissed unfairly. Her job was managing the agency's workers. Reflective of contemporary thinking, the agency workers were expressly 'employed under a contract of service with Champion Employment'. This mattered for Miss Wickens because at the time, unfair dismissal claims against businesses with fewer than 20 employees were unavailable. ${ }^{79}$ To have standing, the agency workers needed to count. But Nolan J held agency workers were not employees because the agency's control was minimal, the contract embodied no obligation to find work for those registered and there was a lack of 'continuity, and care of the employer for the employee, that one associates with a contract of service'. ${ }^{80}$ This decision was without precedent and contrary to understandings about agency status since the Employment Agencies Act 1973.81 The second case was O'Kelly v Trusthouse Forte plc. ${ }^{82}$ Trusthouse Forte plc traded as Grosvenor House Hotel on Park Lane. It did regular banqueting events at irregular times. Mr O'Kelly, a wine butler, joined the Hotel and Catering Workers Union with other waiters. He was told he was no longer needed. The tribunal held the waiters were not 'employees' for the purpose of legislation that protected the right to organise. The Employment Appeal Tribunal, chaired by Browne-Wilkinson J, reversed this over the submissions of Alexander Irvine QC for the employers. The EAT held a series of contracts of employment existed, so the right to join a union applied. On further appeal, Irvine QC's argument's crux was that the waiters were 'casual workers' under the Wages Council Order (R6) definition that 'a worker who undertakes engagements on either an hourly or day-to-day basis and has the right to choose, without penalty, whether or not to come to work'. .83

With this lack of 'mutuality of obligation', Irvine QC insisted that a 'casual worker' was the same as an independent contractor. ${ }^{84}$ For the waiters, Stephen Sedley QC argued that 'mutuality of obligation' could not be a decisive factor in characterising the relationship, and even if it was, in this case the real sanction for not accepting work was to not be called again. But the Court of Appeal accepted Irvine QC's arguments and restored the tribunal's decision. When there was no

\footnotetext{
77 [1984] ICR 612, 623, decided on 3 May 1984.

78 [1984] ICR 365, decided 5 October 1983.

79 Employment Protection (Consolidation) Act 1980, s 64A.

80 [1984] ICR 365, 371.

81 eg Processed Vegetable Growers Association Limited v The Commissioners of Customs and Excise [1974] 1 CMLR

113 at [27], per Kenneth Suenson-Taylor QC, 'an employment agency [...] with a view to gain, provides the services of its employees for a consideration.'

82 [1984] QB 90 decided on 20 July 1983.

83 ibid, 96.

84 ibid, 96.
} 
formal obligation to offer work or turn up for it, there was no 'continuing relationship'. This lack of 'mutuality' precluded an employment contract. ${ }^{85}$ It was a contract for something else, but not an employment contract.

So from the 1980s there was a new judicial willingness to put casual workers outside employment protection, and agency workers were out first. Even though the Court of Appeal had said two different things in Nethermere and O'Kelly, the affirmation of the 'continuing relationship' type mutuality in O'Kelly entrenched the message of Wickens. ${ }^{86}$ An employer has been able to rely on an agency as a kind of 'badge of non-enforceability' of employment rights. And with O'Kelly mutuality in place, the agency industry boomed. In the five years before O'Kelly, the number of agencies grew 17 per cent, and in the five years after O'Kelly the number of agencies grew 231 per cent. The numbers of agencies went from 5,057 in 1977 to an estimated 17,000 agencies in 2008.87 The industry consumed around $£ 3$ billion a year in 1993 . Now it is $£ 27$ billion. It appears that, at least partly, the gap in employment rights has served as an unjustified subsidy for the employment agency industry.

After the 1997 election, reinstatement of employment protection was unlikely. Blair's views appeared to be what he had argued for in Nethermere. In 1996 he told the Confederation of German Industry in Bonn,

No new rights for workers [...] we will not be bullied by Brussels [into] automatically accepting Continental style employment policies. ${ }^{88}$

Moreover, Irvine QC had become Lord Irvine LC. In Carmichael v National Power $p l c, 89$ a number of tour guides had requested a written statement of their contracts. They worked four to eighteen hours a week. Lord Irvine LC held that the guides were not 'employees', except perhaps during work hours. ${ }^{90}$ Lord Irvine LC said that the continuing obligation to provide work was the meaning of mutuality of

\footnotetext{
85 ibid, 115-116, 124-125.

${ }^{86} \mathrm{It}$ is worth noting what a courageous precedent O'Kelly purported to set: you can be sacked for organising a union. It was partially reflected in TULRCA 1992, n 4 above, s 142 which provides that an employer may not subject a 'worker' to any detriment for union activity. But the provisions protecting against dismissal (paradoxically) apply merely to an 'employee'. After Wilson and Palmer v United Kingdom [2002] IRLR 568, the government did not amend the law fully when it introduced the Employment Rights Act 2004 to comply, see K.D. Ewing, 'The Implications of Wilson and Palmer' (2003) 32 ILJ 1. However it is plain that dismissal for union organising would be automatically unfair due to the common law and if not ECHR, Art 11, and the duty of rights compliant interpretation under the Human Rights Act 1998, s 3; cf S. Deakin and G. Morris, Labour Law (Oxford: Hart Publishing, 5th ed, 2009) 713.

${ }^{87} \mathrm{HC}$ Written Answers col $74 \mathrm{Mr}$ Michael Forsyth 7 February 1994; Note the 17,000 figure comes from the Recruitment and Employment Confederation membership (which is declining) and is probably understated. In addition, there are 1,159 licenses issued under the Gangmasters (Licensing) Act 2004. This, however, is not a complete guide, because it does not include agencies sending workers from abroad. See also, A. Gray, 'Jobseekers and Gatekeepers: The Role of Private Employment Agencies in the Placement of the Unemployed' (2002) 16(4) Work, Employment and Society 655, 659

88 See J. Sherman, 'Labour changes policy stance on workers' right' (19 June 1996) The Times; also C Hay, The Political Economy of New Labour: Labouring Under False Pretences? (Manchester University Press 1999) ch 4 89 [1999] 1 WLR 2042.

90 ibid, 2047.
} 
obligation. Lord Browne-Wilkinson, who had rejected Irvine's submissions at the EAT stage of O'Kelly, agreed with his 'noble and learned friend on the Woolsack'. So did Lord Goff and Lord Jauncey. Only Lord Hoffmann delivered a considered opinion, but concentrated on the distinction between fact and law in contractual interpretation. He explained the old division of competence between juries and judges and agreed with the Lord Chancellor's decision. Curiously, however, Lord Irvine LC relied on Stephenson LJ in Nethermere for his definition of mutuality. It has already been noted that Stephenson LJ's definition of mutuality was the same as consideration and this explicitly contradicts the Blair/Irvine view. It would therefore seem that 'mutuality of obligation' as a matter of authority has the same meaning as given by Stephenson LJ. Therefore as a matter of authority there is arguably no continuing work requirement. It would seem this is not a barrier to employment contracts existing. However this was not the lesson followed.

Although some courts persevered in stating that no one test is conclusive,,${ }^{91}$ in reality 'mutuality of obligation' became the key test. In Montgomery $\mathrm{v}$ Johnson Underwood $L t d,{ }^{92}$ for example, this is plain. Mrs Montgomery, after two and a half years as a receptionist at Orenstein \& Kopple through the Johnson Underwood agency, was dismissed for making personal phone calls. Buckley J in the Court of Appeal held that the 'irreducible minimum' legal requirement of mutuality of obligation was absent as against Orenstein \& Kopple. The court chose to treat the case as one of standing, even though Mrs Montgomery's claim may in any event have been doubtful, and even though Buckley J recognised that agency workers were to be left in legal limbo. Agency workers had no right to be heard because they were not 'employees', because there is no 'mutuality of obligation'.

But is 'mutuality of obligation' an intellectually coherent concept? Let us focus on the right to reasonable notice under ERA 1996 section 86. This right benefits working people who are unable to negotiate it in their contracts for themselves. It benefits those with unequal bargaining power. ${ }^{93}$ You must, says section 86 , be given a week's notice after one month, two week's notice after two years, and so forth up to twelve weeks after twelve years. Lack of mutuality, says the O'Kelly approach, means no obligation to accept work when it is offered or provide notice before severing the relationship. So it is precisely an obligation like notice before dismissal that is a pre-requisite for the same employment right. In order to have a right to reasonable notice (section 86) you must be an employee (section 230). An employee must have a contract of employment (section 230(1)). A contract of employment means a contract of service (section 230(1)). A contract of service cannot exist without the 'irreducible minimum' of mutuality of obligation. And mutuality of obligation means, apparently, you must have

91 eg Secretary of State for Trade and Industry v Bottrill [1999] ICR 592, 603.

92 [2001] IRLR 269, 275; nb both the Tribunal and the EAT held, unlike Wickens that the agency was the employer.

93 Someone has greater 'bargaining power' when they have wider range of good alternatives than a bargaining partner, consistent with the definition in the Unfair Contract Terms Act 1977, Sched 2(a). 
negotiated a term restricting the termination of a contract, such as reasonable notice. The logical equation of O'Kelly, Carmichael and Montgomery is this:

rights beyond the contract $=$ 'employee' $=$ contract of employment $=$ contract of service $=$ mutuality of obligation $=$ rights beyond the contract in the contract.

It is circular reasoning at its best. To get employment rights you need to have negotiated them already, even though those rights exist precisely because you are not in a position to negotiate for them. Employment rights are on an intellectual merry-go-round. It is more clever, but no better, than saying, 'you don't have statutory rights because your employer didn't want them.'

\section{THE PURPOSIVE APPROACH}

The present approach to the scope of employment protection is legally defective and logically indefensible. It is also chronically doubtful when measured against the purpose of employment legislation. In Byrne Brothers (Formwork) Ltd $\mathrm{v}$ Baird, Underhill QC explained that purpose. ${ }^{94}$ 'The reason,' he said, 'why employees are thought to need such protection is that they are in a subordinate and dependent position vis-à-vis their employers.' ${ }^{95} \mathrm{Mr}$ Baird was a builder, doing work on a standard form sub contractor agreement. He claimed against Byrne Brothers that he was entitled to holiday pay over Christmas under the Working Time Regulations 1998,96 whose scope uses the concept of a 'worker'. This means anyone with a contract of employment or someone who personally performs work and is not a professional client or customer. ${ }^{97}$ Underhill QC said that the same rationale for giving employment protection to 'employees' went for 'workers', so despite a limited contractual right to find a substitute worker when he was ill, a dependant worker such as Mr Baird fell within the Regulations.

In Redrow Homes (Yorksbire) Ltd $\mathrm{v}$ Wright,98 Pill LJ qualified Underhill QC's approach. In a joined appeal involving bricklayers claiming to be within the scope of the Working Time Regulations 1998, Pill LJ said that tribunals should not be deflected from construing the term 'worker' and a contract 'by general policy considerations'. He warned against saying, 'that, because the applicants ought to come within definition of worker, it follows that they do [...] Expressions such as

\footnotetext{
${ }^{94}$ See also, Vernon $\mathrm{v}$ Bethell (1762) 28 ER 838; A Smith, The Wealth of Nations (1776) Book I, ch 2; S. Webb and B. Webb, Industrial Democracy (Longmans, 1897) Part III, ch 2; France v James Coombes \& Co [1929] AC 496, 505-6; O. Kahn Freund, Labour and the Law: The Hamlyn Lectures (London: Stevens \& Sons, 1972) 4; in the United States, see National Labor Relations Act of 1935, s1 and National Labor Relations Board v Hearst Publications, Inc, 322 US 111 (1944).

95 [2002] ICR 667, 677.

${ }_{96}$ Working Time Regulations 1998, SI 1998/1833 (hereinafter 'WTR 1998').

97 ibid, r 2(1).

98 [2004] EWCA Civ 469; [2004] 3 All ER 98.
} 
"degree of dependence" [...] assist little in that task." Instead, Pill LJ urged that the first task was one of construction, to assess whether the bricklayers did in fact personally perform work, and in this instance they did. But Pill LJ could not have meant that the policy context was entirely irrelevant in assessing the contract's form, any more than the business context is irrelevant in assessing the words of a contract. ${ }^{100}$ Indeed, the only reason for which the exercise of construction is undertaken is to find whether employment protection measures would apply. 101 To disregard the reason behind the legislation would run the risk of defeating the purpose of the task itself. Put in this sense, it is precisely because certain groups of workers ought to come within statutory definitions that they do. ${ }^{102}$ In Heydon's case Coke CJ stated,

the office of all the judges is always to make such construction as shall suppress the mischief, and advance the remedy, and to suppress subtle inventions and evasions for continuance of the mischief, and pro privato commodo, and to add force and life to the cure and remedy, according to the true intent of the makers of the Act, pro bono publico. ${ }^{103}$

A strong analogy for how to approach the term 'employee' can be drawn from the leading insolvency case, Re Spectrum Plus Ltd, ${ }^{104}$ where Natwest Bank plc gave Spectrum Plus Ltd credit and contracted in return for a 'specific charge' over Spectrum Plus Ltd's book debts. Like 'employee' under the ERA 1996, the term 'floating charge' is largely undefined in the Insolvency Act 1986. If a charge is 'specific' or 'fixed', then when a company is insolvent, that creditor may take the assets subject to the fixed charge without sharing them with other unpaid creditors. But if the charge is 'floating', employees, their pension funds, unsecured creditors (up to certain limits) and insolvency practitioners must be paid first. ${ }^{105}$ The archetypal case of an asset subject to a fixed charge is a house, or the company van, while at the other end of the 'spectrum' are assets traded from time to time by the company, such as crates of paint delivered on Monday and sold through the week. Because a floating charge can really apply to anything, late nineteenth century legislation mandated that certain vulnerable creditors would get

\footnotetext{
99 [2004] EWCA Civ 469 at [21]-[22].

100 See Investors Compensation Scheme Ltd v West Bromwich Building Society [1998] 1 WLR; Attorney General of Belize v Belize Telecom Ltd [2009] UKPC 11.

101 This is particularly true where the EU is concerned and teleological interpretation is mandatory, Case 106/89 Marleasing SA v La Comercial Internacionale de Alimentacion SA [1990] ECR I-4135 at [8].

102 Cf D. Hume, A Treatise of Human Nature (1739) Book III, part I, s I, saying rightly that one should clearly be more wary of - in the other direction - stating that one may derive what one ought to do from what is the case; cf M. Friedman, Essays in Positive Economics (1957) Part I.

103 (1584) 76 ER 637.

104 [2005] UKHL 41.

105 IA 1986 ss 175, 176A, s 176ZA, Sched 6.
} 
preference over floating charge holders. ${ }^{106}$ This means the totality of a company's assets, future paint and all, cannot be swept up by a single lender who had the bargaining power to contract for security, leaving nothing for those without bargaining power. Lenders want fixed charges to avoid statutory subordination in the creditor queue. The question is how a charge should be defined. Between the house and the paint cans lies a range of assets that can be subject to more or fewer contractual restrictions. There is no clear demarcation. In this situation the House of Lords held that the charges in question on the book debts were floating, because though it was described as a 'specific charge' in the contract and funds were kept in a separate bank account, the company routinely drew on the funds. In reaching this conclusion, Lord Scott said, ${ }^{107}$

recognition that this is the essential characteristic of a floating charge [ie assets are not finally appropriated by the creditor until a future event] reflects the mischief that the statutory intervention to which I have referred was intended to meet and should ensure that preferential creditors continue to enjoy the priority that section 175 of the 1986 Act and its statutory predecessors intended them to have.

Here we have a term, 'floating charge', which like the term 'employee' is undefined in statute. Like the term 'employee', there is no single characteristic of a floating charge, but an essential idea which is used for the purpose of protective legislation. And like the term 'employee', a floating charge can only be distinguished from its opposite through purposive reasoning. The purpose of the exercise must be clear before a meaning can be found.

There are glimmers of a purposive approach in cases interpreting 'employee'. They need to be highlighted more. In Buchan and Ivey $\mathrm{v}$ Secretary of State for Trade and Industry, ${ }^{108}$ Mummery $\mathrm{J}$ held that two directors who owned all the shares of a company that had gone insolvent could not claim compensation from the National Insurance Fund. ${ }^{109}$ Interpreting the term 'employee', Mummery J said, ${ }^{110}$

The context in which the issue of employee or non-employee arises under the 1978 Act is protection of employment. More particularly, the purpose $[\ldots]$ is to provide for state funded compensation to be available for employees employed by those whose businesses have failed financially. It is not the purpose of those provisions to provide compensation to an individual businessman or entrepreneur whose own incorporated business ventures have been unsuccessful.

\footnotetext{
106 See Salomon v A Salomon \& Co Ltd [1897] AC 22, 53; Preferential Payments in Bankruptcy Amendment Act 1897, s 2. 
While the decision and its purposive approach was, with respect, clearly correct on the facts, subsequently in Secretary of State for Trade and Industry v Bottrill, ${ }^{111}$ Lord Woolf MR qualified the decision insofar as Mummery J suggested that being a sole shareholder would act as an absolute bar to being classified as an employee. So where Mr Bottrill was the managing director of the insolvent Magnatech UK Ltd, the fact that he was the only shareholder did not preclude his claim for unpaid wages (, 346.15 a week) from the National Insurance Fund. ${ }^{112}$ Mr Bottrill's sole shareholding was merely a temporary measure before the American Magnatech Group would take over ownership. The purpose of the legislation in both cases was given full effect.

The purposive approach to interpretation is firmly rooted in English law, and the goal is the same whether interpreting a contract, a company's articles or legislation. ${ }^{113}$ Ambiguities in legislation may be resolved by referring to Hansard. ${ }^{114}$ In our search for meaning it would seem that the most relevant point is when the word 'employee' was introduced in the Contracts of Employment Act 1963. This was the first modern employment law statute. ${ }^{115}$ It introduced the right to a written statement of one's contract and reasonable notice before dismissal, after five weeks of employment. Its mechanism of using the 'employee' concept has been transferred from Act to Act up to today. The Minister for Labour who introduced the Bill on the second reading was the Conservative, John Hare MP. The reason for the 1963 Act was this.

The Bill is a part of the Government's plans to provide greater security for workers. This is a time when industry must be quick to adopt improved methods and exploit new techniques if we are to expand our production and maintain our competitive position [...] fear of change and what it can mean is a powerful incentive to resist change and slow it down by all possible means. But if we reduce that fear and give proper consideration and effective help, we can help, I think, to create an atmosphere in which the need for change is accepted and there is co-operation in creating an efficient and flexible economy $[\ldots]$ The only way to secure the advance that is needed for everyone is to lay down minimum standards, as we are doing in the Bill. But I repeat that these are minimum standards. The object of the Bill is not only to bring everybody up to the minimum but also to encourage employers to improve on the minimum on a voluntary basis. ${ }^{116}$

\footnotetext{
111 [1999] ICR 592.

112 ERA 1996, n 3 above, ss 166 and 182.

113 Attorney General of Belize v Belize Telecom Ltd [2009] UKPC 11; [2009] 1 WLR 1988.

114 Pepper v Hart [1992] UKHL 3; [1993] AC 593, 617; Chartbrook Ltd v Persimmon Homes Ltd [2009] UKHL 38; [2009] 1 AC 1101.

115 See S. Deakin and G. Morris, Labour Law (Oxford: Hart Publishing, 5th ed, 2009) 228.

116 Hansard HC vol 671 cols 1503-1505 14 February 1963.
} 
When looking back at Hansard, one cannot simply cherry pick any backbench quip, but may use as strong evidence of Parliamentary intention a clear and unambiguous ministerial statement. ${ }^{117}$ The extract makes plain that the Government did not draw distinctions between 'employee' and 'worker' to leave out a vulnerable tier of people. It is clear that the purpose of the legislation, which used the word 'employee', was to provide security for workers. But it also vividly illustrates that the Government rejected the notion that a worker's security reduced employers' flexibility. Fostering a climate of mutual trust and confidence is seen as the key to productive, economic efficiency. These were the social considerations which gave rise to the legislation. ${ }^{118}$ As a matter of statutory purpose, it can confidently be said that employment rights were designed to cover everyone from the vulnerable up to the truly autonomous, not leaving out agency workers. About the fact that the ERA 1996 ought to and does cover agency workers, there are no two ways, let alone a third way.

\section{IS THERE A WAY FORTH?}

Sadly, over the past two decades, as the basic purpose of employee rights has been undermined, labour lawyers appear to have fallen into despair with the courts. ${ }^{119}$ One solution is Parliament re-legislating. ${ }^{120}$ As suggested above, when the new Directive is due to come in force it would be the ideal time explicitly to close the loophole and state that agency workers are employees. There is no sign of this yet under the Agency Workers Regulations 2010,121 but it may be required, since article 2 of the Directive designates agencies as employers, and article 3(1)(c) says a 'temporary agency worker' is 'a worker with a contract of employment or an employment relationship'. Going further, clearly a comprehensive statute to classify contracts of employment would solve the problem. Or under the Employment Relations Act 1999 section 23, the Secretary of State has the power to explicitly include categories of people within the definition of 'employee'. Lord Wedderburn of Charlton advocated moves on this in debates leading up to the Employment Act 2008.122 But nothing happened. Calls for re-legislation may overlook the issue. More legislation could be passed, but there is little difficulty to find new ways to undermine it. Parliament did not create the problem. The Court of Appeal created the problem in O'Kelly. The problems of agency workers show that both legislation (for equal working time and pay) and purposive judicial reasoning (to maintain employment rights coverage) are needed. There are

\footnotetext{
117 Wilson $\mathrm{v}$ Secretary of State for Trade and Industry [2003] UKHL 40 at [58].

118 cf Seaford Court Estates Ltd v Asher [1949] 2 KB 481, 498-499.

119 See A.C.L. Davies, 'The Contract for Intermittent Employment' (2007) 36(1) ILJ 102, 'Although many labour lawyers have turned to legislative reform proposals in despair at judicial attitudes towards casual workers, it is important not to neglect the potential of the courts as a source of reform.'

120 A suggestion made in Montgomery v Johnson Underwood Ltd [2001] EWCA Civ 318 at [42]-[43] and James v Greenwich LBC [2008] EWCA Civ 35 at [58].

121 See The Agency Workers Regulations 2010 (SI 2010/93). The deadline to implement the Directive, n 11 above, Art 11, is 5 December 2011.

122 Hansard HL col GC81 25 February 2008.
} 
excellent reasons to be optimistic. The common law cannot exist without reason, and experience is showing the damage of the 'mutuality' defect. ${ }^{123}$ The only precondition to the problem's correction is its recognition.

But then it could be argued that if the courts created problems in the past, the courts should not be counted on to take a purposive approach to employment rights in future. ${ }^{124}$ True it may be that from time to time a few metaphorical crooked cords get the better of the golden metwand.125 But nobody would argue that courts should take a stance that actively undermines the purpose of employment rights. Intentionally or not, this has happened. The status of a receptionist of two and a half years in Montgomery is not open to ambiguity. Even in absence of legislation, common law should develop consistently with social principles. ${ }^{126}$

Additionally it could be argued that it is 'too late' for the common law to amend its confusion. Employment agencies have thrived, so an argument could go, because of the expectation that agency status carries with it a badge of nonenforceability for employment rights. For the courts to perform a u-turn now would defeat the legitimate expectations of thousands of employment agencies. Particularly at a time of economic instability, the courts have no place in making socio-economic policy decisions. But arguably the better view is to consider the same questions as did the House of Lords in Re Spectrum Plus Ltd, which is whether changes would give effect to claimants' statutory rights. ${ }^{127}$

The way forth would seem to be, first, recognition that employment rights remedy inequality of bargaining power, protecting the economically dependent, who are unable contract for minimum employment rights. Like the Unfair Contract Terms Act 1977 does for consumers or the Companies Act 2006 does for shareholders, mandatory terms in the ERA 1996 articulate a meaningful conception of that to which employees would truly consent. Employment rights change the internal mechanism of the market place, so that all people can participate at work on a decent footing. This is not a social cost, but an economic investment which boosts productivity and the incentive of people to contribute more to their workplaces.

Second, it follows that the core feature of an employment contract, beyond the irreducible minimum feature of work for a wage, is a relation of economic dependency. The word 'employee' means nothing much in itself, but is important

\footnotetext{
123 To paraphrase E. Coke, Commentary Upon Littleton (1628) 97b and O.E. Holmes, The Common Law (1881) 1 .

${ }^{124} \mathrm{H}$. Collins, 'Independent Contracts and the Challenge of Vertical Disintegration to Employment Protection Law' (1990) 10 Oxford Journal of Legal Studies 353, 377; citing the American cases NLRB v Hersa, 322 US 111 (1944) and contrasting Harrison v Greyvan Lines, 331 US 704 (1947).

125 To adapt the words of Coke CJ in the Case of Proclamations [1610] EWHC KB J22.

126 See Seaford Court Estates Ltd v Asher [1949] 2 KB 481, 498-499 and Liverpool CC v Irwin [1976] QB 319, 332.

127 [2005] UKHL 41; [2005] 2 AC 680 at [38], [65]-[74], [121]-[127].
} 
as a linguistic vehicle to carry mandatory rules. ${ }^{128}$ Economic dependence must be the essential feature because employment legislation makes no sense unless it protects those who, despite the virtue of contractual freedom, do not acquire truly decent terms. Though some would argue this is an unworkable definition, the argument is false because it works in multiple jurisdictions. ${ }^{129}$ It is the core feature of the 'worker' concept used by European Court of Justice. ${ }^{130}$ It should be apparent that the concept of a UK 'worker' goes even further than that in the EU, protecting an even more autonomous category of people, because it operates through the defined exclusion of 'clients' and 'customers'. The UK 'employee' is the same as the EU 'worker'.

Third, it may be reaffirmed that various other indicia, such as degrees of 'control', one's 'badge of organisation', 'integration' or 'personal performance of work' may fill out the essential feature of employment. One could add other tests. For instance, employment status should follow wherever the term of mutual trust and confidence, or a 'master-servant' relation would be construed. ${ }^{131}$ One could, in analogy with consumer law, ${ }^{132}$ draw a heavy presumption of employment status if work is performed personally under a standard form contract. The best way to interpret the idea of 'employee' is to have firmly in mind the purpose behind the exercise, to protect the relatively vulnerable. Until the United Kingdom regresses to a total doctrine of at-will employment, the coverage of employment rights must be completed.

There is, however, an outstanding issue. It is not only the word 'employee' that gives rise to problems. Because how can you have employment rights if there is no employer?

\section{GOING ROUND IN TRIANGLES: THE ‘EMPLOYER' ISSUE}

\section{TRIANGULATION}

It was noted above that the new Directive designates employment agencies as the employers. ${ }^{133}$ But somehow the English cases arrived at the conclusion that many agency workers are without any employer who owes employees duties. Presently denying agency workers employment rights is a theory of implied terms, which starts with a description of agency work as a 'triangular relationship'. This

\footnotetext{
128 cf Denham v Midland Employers' Mutual Assurance Ltd [1955] 2 QB 437, 444.

129 See, eg, A. Freckmann, 'The Employee Under German Law' (2002) 13(9) International Company and Commercial Law Review 331.

130 Cases 397/01-403/01 Pfeiffer v Deutsches Kreuz, Kreisverband Waldshut eV [2005] IRLR 137, para 82.

131 See Mahmud and Malik v Bank of Credit and Commerce International SA [1997] UKHL 23; Lister v Romford Ice \& Cold Storage Ltd [1957] AC 555, 576.

132 Unfair Terms in Consumer Contracts Regulations 1999, r 3; Unfair Contract Terms Act 1977, s 12; and see also $R$ \& B Customs Brokers Ltd v United Dominions Trust Ltd [1988] 1 WLR 321, by which a limited company can be deemed to be a consumer.

133 EU Temporary and Agency Work Directive, n 11 above, Art 2.
} 
geometrical engagement has become very prevalent. ${ }^{134}$ It is intended to highlight differences in the obligations of the client, agency and worker. In Germany the concept is used to specify who is responsible for statutory rights. Peter Schüren writes the leading commentary on the Arbeitnehmerüberlassungsgesetz. (Employee Leasing Act). He describes the German position like this:

All forms of employee leasing are conducted as a three party contract, in which the lessor, the lessee, and the "leased person" are involved. The basis is the employee leasing contract: the lessors commit themselves to provide the lessee with a suitable "leased employee," without the lessee becoming the leased employee's employer. The lessor remains the employer of the leased employee, even during the leasing period. The legal bond between the lessor and the lessee is not a contract of employment. It is a contract under civil law. ${ }^{135}$

German employment agencies are explicitly responsible for giving reasonable notice before fair dismissal and any redundancy. But in the UK, there has been an element of triangulation over responsibility. In Dacas v Brook Street Bureau (UK) $L t d, 136$ the Court of Appeal thought an employment contract would exist between an agency worker and the client after 'considering all the evidence'. But in James $\mathrm{v}$ Greenwich $L B C,,^{137}$ the Court of Appeal said the only contract is with the agency, not a client, because 'implying a contract' with the client is not 'necessary'. Mrs Dacas had worked for Wandsworth LBC (through Brook Street) for four years. She was dismissed for apparent rudeness. Mrs James had worked for Greenwich LBC (through a Brook Street subsidiary) for three years. She was dismissed after she apparently took sick leave without informing the agency or client. Neither Mrs Dacas nor Mrs James could bring a claim against both employers. And each case reached differing conclusions or perhaps no conclusion at all.138 On the ground, triangulating about the 'employer' issue means that agency workers continue to live in legal limbo. An essential precondition to claiming a right is knowledge of what it is. But now, even if agency workers are visible under the scope of employment protection, their rights are illusory.

The implications of James are particularly grim. The Court of Appeal in Muschett $\mathrm{v}$ HM Prison Service has held that an agency worker had no standing for a

\footnotetext{
134 eg M. Freedland, The Personal Employment Contract (Oxford: OUP, 2nd ed, 2003) 43-45; Dacas v Brook Street Bureau [2004] EWCA Civ 217; [2004] ICR 1437 at [9], [17]; Muscat v Cable \& Wireless [2006] ICR 975 at [2]; P. Davies and M. Freedland, Towards a Flexible Labour Market (Oxford: OUP, 2007) 89; James v Greenwich LBC [2006] UKEAT 0006_06_1812 at [24]; C. Barnard, EC Employment Law (Oxford: OUP, 3rd ed, 2006) 482: 'Addressing the problems experienced by agency workers was always going to prove the hardest situation for the Community legislature to deal with due to the triangulation of the relationships involved.'

135 P. Schüren, 'Employee Leasing in Germany' (2001-2) 23 Comparative Labor Law \& Policy Journal 67, 68

136 [2004] EWCA Civ 217.

137 [2008] EWCA Civ 35.

138 ibid at [47].
} 
claim (among other things) for racial discrimination. ${ }^{139}$ Rimer LJ felt bound by James to say it was not 'necessary' to imply a contract with a client, and therefore there was no employment contract on which equality legislation could ride. With respect, the Court of Appeal's oversight of the purpose of the Race Relations Act $1975,{ }^{140}$ precedent, ${ }^{141}$ and its non-derogable duty to give effect to the EU Race Equality Directive, ${ }^{142}$ which is explicit in comprehensive coverage, will be short lived because the Equality Act 2010 makes the position entirely clear. ${ }^{143}$ But unintentionally, the reasoning in James may be encouraging a culture where you can be sacked for having differently coloured skin, so long as you are an agency worker with differently coloured skin. This loophole is arguably even worse than undermining the right to join a union in O'Kelly or the right to job security in Montgomery. Unintentionally, the law on agency workers is attempting to unravel not just collective bargaining, not just the welfare state, but also the civil rights movement.

\section{WORK FOR A WAGE}

The triangular description of agency work should not be allowed to obscure what is an essentially bilateral contract, a wage from the client for work from the worker. An agency is just the middleman, ${ }^{144}$ but a middleman that nevertheless habitually exercises the same power to dismiss, ${ }^{145}$ bargain over pay, require a dress code, demand submission of time sheets, ${ }^{146}$ or require workers to regularly 'touch base' on how things are. On any test for 'employee' status (apart from 'mutuality of obligation') it should be clear that every typical employment agency really exercises the same functions as a typical employer. An agency is no different from a layer of middle management in a large firm, whose failure to abide by a mandatory term of an employment contract would impute vicarious responsibility to the legal employer. By contrast, an atypical agency might be one which has teachers on its books for private tuition with school or university students at their homes. Here the relation of economic dependency (a teacher with more expertise and a more valuable range of options, not in such poor work) would clearly point to self-employment against both the pupil and the agency. This is far removed from the situations of Mrs Montgomery, Mrs Dacas or Mrs James.

\footnotetext{
139 Muschett v HM Prison Service [2010] EWCA Civ 25; See also, Muschett v HM Prison Service (26.8.2009) UKEAT/0132/08/LA, Judge Ansell [30]; East Living Ltd v Sridhar, TSG Services Ltd (4.11.2008) UKEAT/0476/07/RN, Lady Smith [31] and Ruhaza v Alexander Hancock Recruitment [2010] EWCA Civ 29 (EAT decision of Cox J to dismiss a petition of an agency worker for racial discrimination found perverse where there was a probability that the EAT had lost the worker's affidavit.)

140 eg Race Relations Act 1976, s 7; see also Abbey Life Assurance Co Ltd v Tansell [2000] IRLR 387.

141 Harrods Ltd v Rennick [1997] IRLR 583.

142 See the EU Race Equality Directive 2000/43/EC, Macarthys Ltd v Smith [1981] QB 180, 200 and Case 106/89 Marleasing SA v La Comercial Internacional de Alimentacion SA [1991] 1 ECR 4135.

${ }^{143}$ EA 2010, ss 39 and 41.

144 HL Debs col. GC 299, per Baroness Gardner of Parkes (Con) 13 March 2008.

145 cf Cassidy v Ministry of Health [1951] 2 KB 343, 361, Denning LJ: 'the ultimate sanction for good conduct, the power of dismissal.'

146 See Cairns v Visteon UK Ltd [2007] ICR 616.
} 
Why has the principle of joint and several responsibility not been applied to the client and agency, treating both as employers? Until recently the case of Laugher $\mathrm{v}$ Pointer ${ }^{147}$ may have been a bar. A coach driver, hired out to a carriage business, was held to not be the employee of both the carriage business and hirer. ${ }^{148}$ This was probably a policy decision to prevent a multiplicity of actions in the early $19^{\text {th }}$ century, and it was overturned in Viasystems (Tyneside) Ltd $\mathrm{v}$ Thermal Transfer (Northern) Ltd.149 Young Darren had clambered through a duct on Viasystems' building site. The duct broke, hit a sprinkler and caused a flood. Darren was there to work with his mate, who was contracted by CAT Metalwork Services, which was contracted by S\&P Darwell Ltd, which was contracted by Thermal to fix Viasystems' air conditioning (that is, six parties). May LJ held that CAT and S\&P were the employers and were jointly and severally liable in equal proportion under the Civil Liability (Contribution) Act 1978 section 2. Striking a note of caution in the development of this new principle May LJ added, obiter, that,

if the relevant relationships yield dual control it is highly likely at least that the measure of control will be equal. An equal measure of control will not often arise. Dual vicarious liability is most unlikely to be a possibility if one of the candidates for such liability is also personally at fault. It would be entirely redundant if both were. ${ }^{150}$

This may have been an unnecessary qualification. In developing the law, plainly there is always legitimate concern that change may have unforeseeable effects. However, the Civil Liability (Contribution) Act 1978 is flexible enough to accommodate an unequal apportionment of liability, with regard to the fault of either party. ${ }^{151}$ Also there could well be more than two employers. For example, when James was being litigated, Greenwich LBC had reached the point where it had around 700 workers from over a hundred different employment agencies out of a total of around 6,000 council employees (11 per cent of the workforce). So in June 2007 it hired an employment agency (Manpower) to manage the employment agencies. If one employer is personally at fault, multiple liability is not necessarily redundant, because that employer may have gone insolvent. As against a worker who has received no notice before an unfair dismissal, and can in no way be said to herself be at fault, joint and several liability is necessary to give effect to the reasonable expectation that employment legislation will not be defeated.

After Viasystems it should have appeared entirely open for an agency worker to seek compensation for breach of contract from either her agency or the client,

\footnotetext{
147 (1826) 5 B \& C 547.

148 Possible inspiration may have also been found in Matthew 6:23, Luke 16:13, and Thomas 47:1; See also R. Stevens, 'A Servant of Two Masters' (2006) 122 LQR 201.

149 [2005] EWCA Civ 1151; [2006] ICR 327.

150 [2005] EWCA Civ 1151 at [47].

151 See Royal Brompton Hospital NHS Trust v Hammond (No 3) [2002] UKHL 14.
} 
and for agency and client to seek contribution from the other. It has been suggested that tort liability and employment rights embody different policies, ${ }^{152}$ so a definition of 'employee' in one area cannot be exported to another. But in all cases the best justification for mandatory rights is that they create results that one party - whether tort victim or employee - would be unable to have bargained for. ${ }^{153}$ It would probably be preferable that the agency be held liable as the chief employer where there was a failure to give reasonable notice or redundancy. An agency is the chief employer under UK tax laws, in continental jurisdictions, under the new Directive, ${ }^{154}$ and holds itself out as having the special skill for staffing matters. In unfair dismissal cases, however, primary responsibility would preferably lie with those privy to the misconduct. If the misconducting party had gone insolvent, it is fair that the less responsible other is jointly and severally liable as an employer, because clients and agencies freely choose to contract a substantially less free worker into that arrangement. This logical solution still hangs on the verge of being adopted, because the existence of any employment contract is being denied. We shall now look at three arguments for denial.

\section{DENYING ANY CONTRACT}

Building by order of complexity, let us first consider the situation, as arose on the facts in James, 155 where a written agreement expressly characterises itself as 'a contract for services', or not one of employment. Clearly the agency or client's formulation is not definitive of the substance of the arrangement, especially where it is simply an attempt to avoid employment rights. ${ }^{156}$

Second, what about the situation where a written agreement between worker and agency (or the client) contains a long clause effectively saying, "this is not a legally enforceable contract"? This could be a way for a client to avoid any employment related responsibility. But could it differ from a term saying, "you agree you get no notice or redundancy in any circumstance"? It would seem that the relevant rule is whether there is an 'intention to create legal relations'. This rule is inappropriately worded, because the real policy is that courts presume people want to enforce agreements in the commercial sphere, but not in the domestic sphere. ${ }^{157}$ Presumptions are rebuttable, so commercial parties may manifest true

\footnotetext{
152 Cairns v Visteon UK Ltd [2007] ICR 616 at [16]-[17].

153 An interesting argument, that vicarious liability is an implied term of indemnification in employment contracts is made by J. W. Neyers, 'A Theory of Vicarious Liability' (2005) 43 Alberta Law Review 287; Lister v Romford Ice \& Cold Storage Co Ltd [1957] AC 555 made it less of a mandatory rule by holding that the employer could recover the costs from the employee, but this old decision is highly doubtful after Williams v Natural Life Health Foods Ltd [1998] 1 WLR 830, 838.

154 See Income Tax (Earnings and Pensions) Act 2003, Part 2, ch 7; Social Security (Categorisation of Earners) Regulations 1978, SI 1978/1689; See also EU Temporary and Agency Work Directive, n 11 above, Art 2.

155 [2007] ICR 577 at [9]

156 Ferguson v Dawson Ltd [1976] 1 WLR 1213, 1222, Megaw LJ emphasised that declarations of selfemployment are to be disregarded if the 'realities of the relationship' show otherwise.

157 S. Hedley, 'Keeping Contract in its Place - Balfour v Balfour and the Enforceability of Informal Agreements’ (1985) 5 OJLS 391.
} 
consent to not be bound. In Rose \& Frank Co Ltd v JR Crompton Bros, Rose \& Frank had agreed to distribute JR Crompton Bros' carbon paper in America. They expressly said that the agreement 'shall not be subject to legal jurisdiction in the Law Courts'. Their relationship broke down. JR Crompton Bros refused to continue the agreement and Rose \& Frank tried to sue. In the Court of Appeal Atkin LJ said,

I have never seen such a clause before, but I see nothing necessarily absurd in business men seeking to regulate their business relations by mutual promises which fall short of legal obligations, and rest on obligations of either honour or self-interest, or perhaps both. ${ }^{158}$

Atkin LJ's decision was endorsed by the House of Lords, ${ }^{159}$ and it should be clear that his emphasis on how 'business men' in 'business relations' might structure their affairs means the ability to contract out of contract enforcement would be possible only if both parties contract on equal footing. The right to seek the protection of the courts is a right which cannot be given up, as a matter of public policy, unless the parties can clearly protect themselves. ${ }^{160}$ Workers cannot because they do not have equal bargaining power.

Third, let us suppose that some form of written agreement existed with an agency but not the client (or vice versa). And let us further suppose that the agency is now insolvent, or the worker has not been advised to sue both, again as in James. This is what Mummery LJ tentatively viewed the current law to be:

In many cases agency workers will fall outside the scope of the protection of the 1996 Act because neither the workers nor the end users were in any kind of express contractual relationship with each other and it is not necessary to imply one in order to explain the work undertaken by the worker for the end user. ${ }^{161}$

It is not entirely clear why Mrs James, having worked with Greenwich for three years, did not have a contract through conduct. ${ }^{162}$ No form is required for the conclusion of an employment contract. ${ }^{163}$ If I get on a London Routemaster, sit down and give the bus conductor a pound, without discussing what we are doing, there is an obvious offer as the bus door is open, and an obvious acceptance when

\footnotetext{
158 [1923] 2 KB 261, 293.

159 [1924] AC 445, 455 .

${ }^{160}$ See also, $M$ \& $P$ Steelcraft Ltd v Ellis [2008] ICR 578 at [21], [44], [63] and P. S. Atiyah, An Introduction to the Law of Contract (Oxford: Clarendon, 5th ed, 1995) 153.

161 [2008] EWCA Civ 35 at [51].

162 Brogden v Metropolitan Railway Co (1876-77) LR 2 App Cas 666; Datec Electronic Holdings Ltd v United Parcels Service Ltd [2005] EWCA Civ 1418.

163 The right to a written statement of one's employment contract under ERA 1996, n 3 above, s 1 is a right, not a requirement.
} 
I get on, with a clear mutual exchange of consideration. Now let us suppose that the bus conductor was the employee of Conductors Ltd, a recently outsourced firm separate from Transport for London. And suppose that TfL's contract with Conductors Ltd expressly denied that Conductors Ltd had the authority to form any contract, particularly a consumer contract, on its behalf with passengers. The driver, who is TfL's employee, crashes. Conductors Ltd has gone insolvent. Can I claim a refund from TfL? Surely there was a contract, and TfL breached its statutory duty of care and skill. An exclusion clause between TfL and Conductors Ltd could not have the effect of denying a contractual obligation to me, because it would be a variety of an unreasonable exemption clause under the Unfair Contract Terms Act 1977 section 13. In what sense was it any different for Mrs James? She came to work. The council gave her work. She was paid. A contract therefore arises.

The reasoning in James was that 'implying a contract' (ie recognising a contract formed) was impossible unless a 'necessity' test is fulfilled. Mummery LJ relied on The Aramis where Bingham LJ stated,

whether a contract is to be implied is a question of fact and that a contract will only be implied where it is necessary to do so [...] it would, in my view, be contrary to principle to countenance the implication of a contract from conduct if the conduct relied upon is no more consistent with an intention to contract than with an intention not to contract. It must, surely, be necessary to identify conduct referable to the contract contended for or, at the very least, conduct inconsistent with there being no contract made between the parties. Put another way, I think it must be fatal to the implication of a contract if the parties would or might have acted exactly as they did in the absence of a contract. 164

Firstly, it is important to assess this statement together with Bingham LJ's opinion in Blackpool and Fylde Aero Club Ltd v Blackpool BC, ${ }^{165}$ when he revisited the same question. Here he expressly referred to the 'confident assumptions of commercial men' while saying that one should 'be able to conclude with confidence both that the parties intended to create contractual relations and that the agreement was to the effect contended for'. 166 Like in Rose \& Frank, the emphasis on what 'commercial men' did 'intend' suggests a set of cases wholly inapplicable to the context of employment. Business and commerce are not the same, because an employment relationship is one characterised by inequality of bargaining power.

Secondly, it is important to consider the other implied contract cases. In Baird Textile Holdings Ltd $\mathrm{v}$ Marks \& Spencer plc ${ }^{167}$ a supplier of thirty years to M\&S was dropped without any notice. Baird Textile argued that there was a duty to give

\footnotetext{
164 [1989] 1 Lloyd's Rep 213, 224.

165 [1990] 1 WLR 1195.

166 [1990] 1 WLR 1195, 1201-1202.

167 [2001] EWCA Civ 274.
} 
reasonable notice before it was dropped, but faced the difficulty that no long-term supply agreement had been concluded. M\&S argued that each delivery was a discrete transaction. The Court of Appeal held there could be no implied contract because it was not necessary. 'It could not be right,' said Mance LJ, 'to adopt a test of necessity when implying terms into a contract and a more relaxed test when implying a contract - which must itself have terms. ${ }^{168}$

By parity of reasoning, it could not be right to have automatic application of employment rights through statute, but then adopt a more stringent test for implying a contract - which must exist to have the right. Moreover, the implication of a contract in this context, according to the distinction drawn in Liverpool CC $\mathrm{v}$ Irwin, 169 should be wholly a matter of law, or a contract 'implied in law', not one 'implied in fact' as the decision in James assumes. There is no basis to argue that the existence of a contract, which would ensure the efficacy of legal rights, is not a necessary incident of the worker's employment.

Thirdly, even if that were wrong, and we must deal with an 'implied in fact' contract, the 'necessity test' used in James and The Aramis is incomplete and outdated. The older cases, such as The Moorcock,170 Shirlaw v Southern Foundries (1926) Ltd, ${ }^{171}$ and Scally v Southern Health and Social Services Board ${ }^{172}$ suggested that terms should be implied on the basis of what the parties 'would have agreed' had they been asked. But the law developed. Since Paragon Finance plc $\mathrm{v}$ Nash ${ }^{173}$ and Equitable Life Assurance Society v Hyman, ${ }^{174}$ the question for 'individualised implied terms' (terms implied in fact) is, what is 'strictly necessary [...] to give effect to the reasonable expectations of the parties'? Implied terms are not to be avoided just because the court does not deem them necessary or, as Mummery LJ considered, because there is 'some other explanation'. ${ }^{175}$ Asking 'what is necessary' in isolation is a deeply elusive question. ${ }^{176}$ The court must ask whether the implication of the contract is necessary to fulfil the parties' reasonable expectations. When an elected Parliament legislates to protect vulnerable people, it is a reasonable expectation that a tribunal or court shall not allow that purpose to be defeated. It is

\footnotetext{
168 ibid at [62].

169 [1976] UKHL 1, concerning a term implied in law, or one which arises as a necessary incident to the category of agreement. In this case the term was that the landlord council should keep the stairwells in decent repair (though tenants were also expected to do their part, and in this instance the council was not in breach).

170 (1889) 14 PD 64, 68, implying a term that the owner of a pier (and not the owner of the unloading ship) should ensure the berth would be free from hazardous obstacles was necessary.

171 [1939] 2 KB 206, 227, implying a term that a managing director would not be removed from his office for the duration of a ten-year contract with the company.

172 [1992] 1 AC 294; see also F. Reynold QC, 'The Status of Agency Workers: A Question of Legal Principle' (2006) ILJ 323. Reynold QC was the counsel who won in Scally, but wrote this note just after the Court of Appeal in Muscat v Cable \& Wireless plc [2006] ICR 975 held that an employee who was reengaged in the same job through an agency could not have suddenly lost all ERA 1996 rights.

173 [2001] EWCA Civ 1466 at [36], [42].

174 [2002] 1 AC 408, 459.

175 As is suggested in James [2008] EWCA Civ 35 at [30], [42], [51]

176 Crossley v Faithful \& Gould Holdings Ltd [2004] EWCA Civ 293; [2004] ICR 1615 at [36].
} 
respectfully submitted that in James the Court of Appeal erred in the test for implied terms, and there was every reason to find an implied, or if not, an express contract and to try the substantive claim.

The law on implied terms is continuing its development. Through Investors' Compensation Scheme $\mathrm{v}$ West Bromwich BS, 177 BCCI SA v Ali, ${ }^{178}$ The Achilleas ${ }^{179}$ and Attorney General of Belize v Belize Telecom Ltd, ${ }^{180}$ it has been consistently held that the best method of interpretation, or construction, is to view an agreement from the perspective of a reasonable person with knowledge of all relevant background facts. In this light, implied terms are merely part of a broader process of construction, necessary to understand any instrument. The court should construe contracts, company articles and statutes in the same way: sensitive to the context and consistent with the purpose of the agreement. This is the best kind of jurisprudence, and is based on sound authority. As Denning LJ said, a judge,

must set to work on the constructive task of finding the intention of Parliament, and he must do this not only from the language of the statute, but also from a consideration of the social conditions which gave rise to it, and of the mischief which it was passed to remedy, and then he must supplement the written word so as to give "force and life" to the intention of the legislature. ${ }^{181}$

At its simplest the issue may come down to this. If a person would have had employee status, had she been directly contracted, the situation does not change just because an agency is interposed. A different result is not consistent.

\section{SQUARING UP}

Two final cases capture the state of English jurisprudence. In Astbury v Gist Ltd, ${ }^{182}$ Mr Astbury claimed that he was an employee of Gist's warehouse in his job of two and a half years. Gist supplied food to Marks \& Spencer and it recruited $\mathrm{Mr}$ Astbury through Pertemps, which (remarkably like a middle management) had its office on-site. He applied for a permanent position three times. Three times he was turned down. Then he was let go and he represented himself in an unfair dismissal claim. He could not show he was a Gist employee. After that he got another job, through Adecco in Bentley's warehouse. Mr Astbury started telling

\footnotetext{
177 [1997] UKHL 28.

178 [2001] UKHL 8.

179 [2008] UKHL 48

180 [2009] UKPC 11.

181 Seaford Court Estates Ltd v Asher [1949] 2 KB 481, 498-499; See also, R. Dworkin, Law's Empire (Oxford: Hart Publishing, 1998) 219, 'Integrity demands that the public standards of the community be both made and seen, so far as this is possible, to express a single, coherent scheme of justice and fairness in the right relation. An institution that accepts that ideal will sometimes, for that reason, depart from a narrow line of past decisions in search of fidelity to principles conceived as more fundamental to the scheme as a whole.'

182 [2007] UKEAT 0619/06/2803.
} 
people that Bentley was his true employer. He then wrote to Adecco that he was terminating his contract with them. Adecco phoned Bentley, and they removed him from the premises. In Astbury v Bentley Motors Ltd, ${ }^{183} \mathrm{Mr}$ Astbury was again turned away for want of standing. Here was a man who simply wanted to be dealt with squarely, and not be treated differently. It was not unreasonable for him to believe that the company paying his wage, giving him work, a uniform and a livelihood was his employer. Perhaps Mr Astbury had been dismissed fairly on both occasions. But he should be told this, and not told that he was different because he was an agency worker.

It is not unlikely that what underlies much opinion about agency workers' rights reflects the following view. When you work through an agency, you are going for temporary work where nobody will expect you to stay. If you want to leave tomorrow, you can. So the employer should therefore not have to abide by employment rights when you need not do the same. This is an old fashioned opinion about freedom of contract. ${ }^{184}$ It does not acknowledge that some people are more free than others, that a human is not a resource. People apply for jobs at agencies because they need jobs and agencies are a source of jobs. Some people who oppose agency worker rights consider employment rights as generally undesirable. But if employment rights are wrong, then they should exist for nobody. There does not seem to be any good reason for singling out agency workers as a special category of unprotected people, or as part of a broader group of the most vulnerable, who will not benefit from the bare minima in UK employment rights. If we want to continue living in a two-tier society, with a growing underclass of women, migrants, young people and manual labourers who have little more than a minimum wage and compensation for injuries, the present situation is good. But if that is not acceptable, then it must be recognised that agency workers should not be treated differently.

\section{CONCLUSION}

Should agency workers be treated differently? No. The compelling similarity between people at work is the work they do, not their status. The new Directive should be seen as another category of anti-discrimination policy, which combats attempts to treat people less favourably for a status not freely chosen. But equality in 'basic working conditions', which the Directive explicitly instates, is not enough for UK law.

183 (9.5.2007) Unreported, Appeal No. UKEATPA/1844/06/DA; Underhill J decided the case on the basis of The Aramis and the lack of control.

184 See Vernon v Bethell (1762) 28 ER 838; George Mitchell (Chesterhall) Ltd v Finney Lock Seeds Ltd [1983] QB 284, 297; in the United States, see West Coast Hotel Co v Parrish, 300 US 379 (1937). 
So the changes I advocated were essentially twofold. Firstly, I argued that we need smarter regulation. To effectively enforce the equal rights agency workers will gain and to make enforcement of the existing rules realistic, agency licensing should be reintroduced. This would only mean making the position the same as for the licensees under the Gangmasters (Licensing) Act 2004. I also suggested that more streamlined enforcement would result if EASI and the GLA were merged with one another. Furthermore I suggested that all fees for jobs should be banned, because fees in the wrong place inhibit the successful functioning of the labour market. The only fair exception is fees from agencies to clients, but these should be disclosed to all parties to ensure fees are properly negotiated and to ensure the Directive's purpose of equal pay is transparently achieved.

Secondly, I argued that typical agency workers are the employees of both the agency and the client. I demonstrated why a purposive approach to defining the word 'employee' is necessary and why 'mutuality of obligation,' as presently understood, is an intellectually moribund criterion, suffused with circular reasoning. It is circular because built into the definition of 'mutuality of obligation' is the need to have contracted for the very rights that employee status would guarantee. The fact that many agency workers are unable to contract for the minimum rights in employment legislation alone warrants that mandatory rights should be provided. Furthermore, both a client and an agency can be deemed joint and several employers. The modern view of construction and implied terms requires that effect be given to agencies', workers' and employers' reasonable expectations. Courts need not refuse to find an 'implied contract' simply because there is 'some other explanation' for the arrangement. Everyone should expect that when Parliament has legislated to provide mandatory rights for the vulnerable, the courts would not let that aim be defeated. Britain loses by sticking with its laissez faire attitude towards productive economic policy, and will gain greatly when the courts remove these legal anomalies. The work-wage bargain does not change because an agency is in the middle. 